\title{
La reconversión del comercio minorista: comercio virtual, precios dinámicos y costos de búsqueda
}

The Reconversion of Retail Trade: e-Commerce,

Dynamic Pricing and Search Costs

A reconversão do comércio varejista: comércio virtual,

preços dinâmicos e custos de busca

Nicolás Ignacio Oviedo

Universidad de Buenos Aires -

Universidad Torcuato Di Tella, Argentina

E-mail: nicolasignoviedo@gmail.com

Fecha de recepción: 07/06/2019

Fecha de aceptación: 11/09/2019

Palabras clave

- Comercio virtual

- Precios dinámicos

- Comercio minorista

- Costos de búsqueda

\section{Resumen}

En este artículo se relevan cualitativamente las principales transformaciones que el comercio virtual induce sobre la dinámica tradicional del comercio minorista. El argumento principal es que el comercio virtual no es meramente la traslación al ciberespacio de la lógica del mundo físico. Los cambios de mayor magnitud que identificamos son dos. Por un lado, para las firmas se torna más asequible establecer un sistema de precios dinámicos con discriminación de primer grado para maximizar beneficios. Por el otro, las transacciones digitales implican el ahorro de los costos de búsqueda para los consumidores típicos del comercio minorista clásico. Un corolario significativo es que, para estudiar empíricamente el fenómeno, se deben adaptar y combinar enfoques teóricos. Adaptaciones de modelos de shopping time con firmas que realizan discriminación de precios de primer grado bajo ciertas restricciones lucen como enfoques promisorios para futuros estudios empíricos.

\footnotetext{
Abstract

In this article, the main transformations on the retail business dynamics that e-commerce entails are reviewed. We state that e-commerce is not merely the linear translation of the physical world logics to the virtual envi-
} 
Keywords

- E-commerce

- Dynamic pricing

- Retail business

- Search costs

ronment. Novelty is twofold. On the one hand, firms can more easily put dynamic pricing schemes into practice, with first-degree price discrimination in order to maximize benefits. On the other hand, typical shopping and search costs for consumers are reduced in the digital marketplace. A major corollary is that it is necessary to adapt and combine different models to empirically approach the topic. Variations of shopping-time models with enterprises that discriminate prices (subject to certain restrictions) seem like promising frameworks for a future investigation agenda.

\section{Resumo}

Neste artigo relevam-se qualitativamente as principais transformações que 0 comércio virtual induz sobre a dinâmica tradicional do comércio varejista. 0 argumento principal é que 0 comércio virtual não é apenas a translação para o ciberespaço da lógica do mundo físico. As maiores mudanças que identificamos são duas. Por um lado, torna-se mais acessível para as empresas estabelecerem um sistema de preços dinâmicos com discriminação de primeiro grau para maximizar seus lucros. Por outro lado, as transações digitais implicam a poupança dos custos de busca para os consumidores típicos do comércio varejista clássico. Um corolário significativo é que, para estudar empiricamente o fenômeno, devem-se

Palavras-chave

- Comércio virtual

- Preços dinâmicos

- Comércio varejista

- Custos de busca adaptar e combinar abordagens teóricas. Adaptações de modelos de tempo de compra com empresas que fazem a discriminação de preços de primeiro grau sob certas restrições, apresentam-se como abordagens promissórias para futuros estudos empíricos. 